\title{
Barbara Mazur
}

\section{Metodologiczne aspekty uczenia się z różnorodności organizacji}

Kod JEL: Z1

Słowa kluczowe: różnorodność kulturowa, organizacja, uczenie się

Streszczenie. Współczesne organizacje przestają być jednorodne kulturowo. W wyniku zjawisk demograficznych i ekonomicznych wiele milionów ludzi migruje w poszukiwaniu pracy i lepszego życia, zmieniając nie tylko miejsce zamieszkania, ale także środowisko kulturowe, do którego wkracza z własnymi wartościami, normami i zasadami postępowania. Zatem zarówno pracownicy, jak i przedsiębiorstwa są wyeksponowane na różnorodność. W wyniku globalizacji, procesów migracyjnych oraz integracyjnych zasoby ludzkie licznych organizacji stanowią mieszankę kulturową. W literaturze na temat zarządzania różnorodnością kulturową jest ona określana jako obosieczny miecz mogący działać na korzyść organizacji lub być dla niej obciążeniem. Rolą zarządzających jest spowodować, by mieszanka ta stanowiła dla organizacji źródło przewagi konkurencyjnej. Aby tak się mogło stać, organizacje muszą wypracować metody wzajemnego uczenia się od odmiennych kulturowo członków grup. Podstawę artykułu stanowi przegląd literatury na temat metod uczenia się od odmiennych kulturowo członków organizacji. W świetle uzyskanych wyników badania literaturowego najskuteczniejszą metodą uczenia się z różnorodności kulturowej jest przyjęcie przez organizację szczegółowych mentalnych struktur uczenia się ufundowanych na dwóch czynnikach: perspektywie integracji i uczenia się oraz ogólnych strukturach uczenia się. 


\section{Wprowadzenie}

Dotychczasowe badania organizacji potwierdzają możliwości zarówno pozytywnego, jak i negatywnego oddziaływania różnorodności na ich działalność; wypływa z nich również wniosek, że grupy heterogeniczne stoją wobec szans i zagrożeń obcych grupom homogenicznym (Shaw, Barrett-Power, 1998). Heterogeniczność grupy wzbogaca jej działania dzięki większej kreatywności członków i różnorodnym sposobom myślenia. Między zróżnicowaniem a kreatywnością zachodzi wzajemna relacja - nie można być kreatywnym, nie kojarząc idei uznawanych dotychczas za rozbieżne. Skoro chodzi o powiązanie idei od siebie odległych, to ich źródła również muszą być zróżnicowane, a zatem kreatywnością rządzi równanie dużego ryzyka i dużego zysku (Trompenaars, Hampden-Turner, 2005). Z drugiej strony istnieje niebezpieczeństwo obniżenia wyników działań, ponieważ różnorodność bywa jednocześnie źródłem nieporozumień i konfliktów. Zróżnicowanie traktowane jest jako jeszcze jeden czynnik ryzyka podejmowanego w momencie zakładania przedsiębiorstwa. Zaangażowanie grup względnie jednorodnych jest mniej ryzykowne i zmniejsza niebezpieczeństwo porażki, ale - z drugiej strony potencjalne osiągnięcia mogą być bardziej umiarkowane. Im bardziej zróżnicowana jest grupa pracowników, tym trudniej nią zarządzać - ale tym większych korzyści można się spodziewać w przypadku dobrego zarządzania.

Celem artykułu jest przegląd literatury na temat organizacyjnego uczenia się z różnorodności kulturowej oraz wskazanie najlepszej metody skutecznego uczenia się w organizacji. Artykuł ma charakter formalny.

\section{Różnorodność i jej wymiary a organizacyjne uczenie się}

Mimo że różnorodność ma globalny charakter, to nie można jej rozumieć jedynie w kulturowych i językowych granicach, gdyż jest uzależniona od wielu czynników historycznych, politycznych i kulturowych poszczególnych krajów. Aby właściwie uchwycić znaczenie różnorodności, należałoby zbadać, jak tworzyły się jej kategorie w poszczególnych krajach. Jak wynika z badań M. Mor Barak (2005), dla jednych jest to kategoria rasowo-etniczna (USA), religijna (Irlandia), a dla innych - społeczna (Indie).

Wielu badaczy przy definiowaniu różnorodności odwołuje się do jej wymiarów. Należą do nich Loden i Rosener (1991, za: Rijamampinina, Carmichael, 2005, s. 109), którzy definiują różnorodność jako to, co odróżnia jedną grupę ludzi od drugiej w odniesieniu do pierwotnych i wtórnych wymiarów różnorodności. Do wymiarów pierwotnych należą płeć, przynależność do określonej grupy etnicznej, rasa, 
orientacja seksualna, wiek, psychiczne i fizyczne zdolności oraz charakterystyczne cechy. Wtórne wymiary różnorodności obejmują: edukację, status rodzinny, styl pracy, doświadczenie w pracy, doświadczenie militarne, miejsce i rolę w organizacji, poziom dochodu i styl komunikacji. Arredondo (2004, za: Rijamampinina, Carmichael, 2005, s. 109) do pierwotnych wymiarów różnorodności dodaje także kulturę, przynależność do klasy społecznej, język oraz poglądy na temat tego, jak troszczyć się o własne zdrowie oraz w jaki sposób wypoczywać. Dodaje ona także trzeciorzędne wymiary różnorodności, które obejmują doświadczenia minionych czasów.

Hubbard (2004, s. 29-32), podobnie jak Loden i Rosner, do pierwotnych wymiarów różnorodności zalicza: wiek, przynależność etniczną, płeć, specyficzne cechy psychiczne i fizyczne, rasę i orientację seksualną. Wybór wymienionych wymiarów uzasadnia bardzo istotnym ich oddziaływaniem podczas wczesnych etapów socjalizacji oraz silnym i nieustannym wpływem na każdym następnym etapie życia. Wymienione elementy tworzą zasadniczy zrąb osobowości człowieka doświadczającego świata. Poza wskazanymi sześcioma cechami tworzącymi pierwotny wymiar różnorodności, pozostają inne tworzące jej wtórny wymiar, który obejmuje: sposób komunikowania, edukację, status rodzinny, doświadczenia militarne, rolę w organizacji i miejsce w jej strukturze, religię, język ojczysty, pochodzenie geograficzne, dochody, doświadczenie zawodowe oraz styl pracy. O wymiarach wtórnych można powiedzieć, że chociaż są mniej widoczne niż pierwotne, to w bardziej zróżnicowanym stopniu wpływają na poszczególnych ludzi. Ludzie mając więc wpływ na wymiary wtórne mogą, do pewnego stopnia, kontrolować je i wybierać. Wymiary te cechuje także mniejszy wpływ na życie ludzkie, ponieważ większość ludzi jest świadoma ich oddziaływania w danej chwili w odróżnieniu od oddziaływania wymiarów pierwotnych. Chociaż uznaje się, że wymiary pierwotne odgrywają niezwykle istotną rolę w życiu każdego człowieka, to wymiary wtórne, jak się wydaje, także są nie do przecenienia. Dopiero oba wymiary łącznie umożliwiają dostrzeżenie i uchwycenie wyjątkowości każdego człowieka, sięgając daleko głębiej niż tylko do przynależności etnicznej czy stylu komunikowania się. Jedynie w połączeniu, jak podkreśla Hubbard (2004), umożliwiają one określenie wyjątkowości i niepowtarzalności każdego człowieka.

Z kolei Rijamampinina i Carmichael (2005) przekonują, że różnorodność można ujmować nie w dwóch, a w trzech wymiarach, z których każdy obejmuje inne aspekty. Wskazują oni na analogię między różnorodnością a górą lodową - cechy oczywiste, takie jak rasa, etniczność, płeć, wiek i upośledzenia odnoszą się do jej wierzchołka i są podstawą antydyskryminacyjnych ustaw prawnych. Inne cechy, takie jak religia, kultura, orientacja polityczna są mniej oczywiste i pozostają ukryte tuż pod powierzchnią wody; wymiar ten może się wraz z upływem czasu ujawniać. Wymiar trzeci, usytuowany głęboko pod powierzchnią wody, stanowi o prawdziwej 
istocie różnorodności, a jego ujawnienie wymaga najdłuższego okresu. Jest on uznawany za centralny dla tożsamości człowieka i to on w największym stopniu stanowi źródło organizacyjnego uczenia się.

Różnorodność pracowników pociąga za sobą wielość i różnorodność informacji, które mogą oni zgromadzić i przetworzyć oraz wielość perspektyw, jakie mogą przyjąć, dążąc do osiągnięcia założonych celów. Posiadanie informacji nie wynika z samej różnorodności pracowników, jako że zasoby informacyjne w różnorodnej grupie pozostają często w ukryciu. Wynikać to może z tego, że członkowie takich grup są często nieświadomi korzyści wynikających z wymiany informacji lub są niewystarczająco umotywowani, by je wykorzystać w dochodzeniu do celu. Pieterse, Knippenberg i Dierendonck (2012) wskazują na cztery orientacje odnoszące się do uczenia się w organizacji. Są to:

- podejście zorientowane na uczenie się - oparte na przekonaniu, że wiedzę i kompetencje można rozwijać,

- podejście zorientowane na unikanie uczenia się - oparte na przekonaniu, że przede wszystkim należy dążyć do tego, by nie utracić nabytej uprzednio wiedzy i kompetencji,

- podejście zorientowane na działanie - oparte na założeniu, że trzeba demonstrować własne kompetencje porównując się z innymi,

- podejście skierowane na unikanie działania - oparte na założeniu, że należy unikać działań, w których wychodzi na jaw niekompetencja pracowników.

Odnosząc przedstawione podejścia do różnorodności kulturowej pracowników, wskazani autorzy uznają, że dwa podejścia: podejście zorientowane na uczenie się i podejście polegające na unikaniu działań mogących odkryć niekompetencje, są kluczowe. Jak wynika z ich badań, stopień osiągnięcia założonych celów jest w grupie różnorodnej kulturowo tym większy, im bardziej grupa ta wcieliła w swoje działania podejście zorientowane na uczenie się, a różnorodność kulturowa jest pozytywniej związana z działaniem w tych grupach, w których podejście skierowane na unikanie działań występuje w stopniu minimalnym.

\section{Uczenie się w grupie jednorodnej vs uczenie się w grupie zróżnicowanej i z wnętrza organizacji}

Skutecznym sposobem prowadzącym do sukcesów zróżnicowanej kulturowo grupy jest uczenie się od innych członków organizacji, uczenie się z różnorodności (Trompenaars, Hampden-Turner, 2005). Jak podkreśla Koźmiński „uczenie się organizacji jest procesem refleksyjnym, w którym uczestniczą członkowie na wszystkich 
jej szczeblach i który obejmuje zbieranie informacji z otoczenia zewnętrznego. Te informacje są filtrowane w zbiorowym procesie nadawania znaczeń, a jego rezultatem są powszechnie podzielane interpretacje, które mogą być wykorzystywane $\mathrm{w}$ inicjowaniu działań prowadzących do trwałych zmian w zachowaniu organizacji i stosowanych w praktyce teorii" (Koźmiński, 2004, s. 111).

Warunkiem skutecznej nauki z różnorodności jest poczucie „,psychologicznego bezpieczeństwa”, wynikające z przekonania o istnieniu gwarancji bezpieczeństwa przy podejmowaniu interpersonalnych działań obciążonych ryzykiem. Oczekiwanie na informację zwrotną, dzielenie się wiedzą i zwracanie się o pomoc, to niektóre elementy zachowań grupy uczącej się, tworzącej kulturę akceptacji różnorodności sprzyjającej wydajności pracy (Cichorzewska, Rakowska, 2016).

Grupy zróżnicowane są odmienne od grup homogenicznych i ogólne zasady uczenia się i nabywania umiejętności mogą okazać się niewystarczające, by wystąpił w nich proces uczenia się. Członkowie grup jednorodnych kulturowo cechują się podobnym pochodzeniem etnicznym, poziomem wykształcenia i rodzajem zdobytego doświadczenia, które determinują ich sposób postrzegania świata. Tożsamość grupy nie wynika jedynie z kulturowego podobieństwa, ale także z podobnego statusu społecznego i podzielanych zainteresowań. Liczne badania potwierdzają, że grupy zróżnicowane kulturowo charakteryzują się inną od grup homogenicznych dynamiką, a czynniki warunkujące tę odmienność są wielorakie i złożone. Można je zestawić wysuwając argumenty, które poniżej przedstawiono.

Po pierwsze, członkowie grup zróżnicowanych kulturowo mają odmienne doświadczenia życiowe, które ukształtowały ich wartości, podejścia i stanowiska. Członkowie takich grup mogą różnić się zarówno w sposobie definiowania i podchodzenia do problemu, strukturalizowania dyskusji, postrzegania możliwych rozwiązań, jak i podejmowania decyzji. Różnice te mogą stanowić zaczyn konfliktu w grupie lub też okazać się impulsem pobudzającym kreatywność (Chatman, Flynn, 2001).

Po drugie, członkostwo grupy jest także związane z wielkością reprezentacji w całej grupie. Mniejszościowi członkowie grup mogą być bardziej świadomi własnej tożsamości, ponieważ różnią się od większości ustanawiającej normę grupy. Członkowie grupy pozostający w większości mogą tworzyć klimat, który będzie powodował, że inni poczują się z niej wyłączani (Ashforth, Meal, 1989).

Po trzecie, różnorodne grupy mają odmienną od jednorodnych dynamikę, ponieważ różnice w posiadaniu i sprawowaniu władzy są funkcją zróżnicowania kulturowego. Będący w większości członkowie grupy mogą bardziej lub mniej świadomie działać w sposób wzmacniający ich dominację - przez określony sposób podejmowania decyzji, określone interakcje społeczne itp. Reprezentanci grup mniejszościowych mogą także przez swoje zachowania, takie jak wycofywanie się 
lub przez komunikowanie się głównie z członkami własnej podgrupy, przyczyniać się do dysfunkcjonalnej dynamiki grupy (Ely, Thomas, 1997).

Wymienione powody mogą przyczynić się do tego, że ogólne struktury grupowego uczenia, które są skuteczne w odniesieniu do grup jednorodnych, bywają niewystarczające dla grup zróżnicowanych. Proces uczenia się wymaga zaufania, które w grupach zróżnicowanych bywa trudniejsze do zdobycia niż w grupach homogenicznych. Błędy mogą mieć większy ciężar gatunkowy w grupach heterogenicznych, ponieważ przyznanie się do nich może być dla ich członków trudniejsze i bardziej dojmujące. Dotyczy to zwłaszcza członków mniejszościowych podgrup, którzy często odczuwają brak wiary we własne umiejętności i możliwości.

Indywidualne odczucia dyskomfortu lub zagrożenia mogą skutkować bardziej skomplikowaną dynamiką grupową (Foldy, 2004). Uznaje się, że grupom heterogenicznym trudniej jest osiągnąć poczucie psychologicznego bezpieczeństwa. W niektórych przypadkach trudna dynamika grupowa połączona $\mathrm{z}$ różnorodnością kulturową może prowadzić do sytuacji, w której wszyscy członkowie, i ci pozostający w grupie większościowej, i ci z grupy mniejszościowej, będą się czuli zagrożeni. Jeżeli dynamikę grupy cechują konflikty oraz brak zaufania, wówczas wydaje się mało prawdopodobne, by ktokolwiek w takiej grupie czuł się bezpieczny, chociaż w określonych przypadkach członkowie grupy dominującej mogą się czuć bezpieczniej od reprezentantów grup mniejszościowych.

\section{Perspektywa różnorodności w procesie uczenia się}

Centralną kategorią w procesie uczenia się w grupach zróżnicowanych jest perspektywa różnorodności i to ona warunkuje jego skuteczność (Earley, Mosakowski, 2000). Perspektywa różnorodności, uznawana za czynnik o kluczowym znaczeniu w relacji między różnorodnością a wydajnością, określana jest jako sposób, w jaki członkowie danej grupy myślą o różnorodności kulturowej i do niej podchodzą. Obejmuje ona ,przekonanie, które kieruje ludzkie wysiłki ku wykreowaniu i reagowaniu na różnorodność kulturową w grupie pracowników; przekonania na temat wartości kulturowej tożsamości w pracy; oczekiwania co do wpływu, jakie różnice kulturowe mogą lub powinny wywierać na grupę i jej działania; przekonania na temat tego, co gwarantuje postęp na drodze do idealnej grupy wielokulturowej" (Ely, Thomas, 2001, s. 234). Perspektywa ta bywa wpisana w misję lub może być częścią polityki różnorodności organizacji. Perspektywa różnorodności danej grupy jest podejściem, w którym podkreśla się, jak członkowie grupy definiują swoje cele i zadania i jak współdziałają w obrębie grupy. Twórcy tego konceptu wyróżniają trzy odmienne perspektywy różnorodności. 
Pierwsza perspektywa - rozróżniania i sprawiedliwości - wiąże się z rekrutowaniem i utrzymaniem pracowników z grup mniejszościowych. Zakłada ona, że takie przejawy różnorodności, jak rasa, narodowość i płeć, nie mają istotnego wpływu na sposób wykonywania pracy i uwzględnianie ich w jej organizowaniu nie przyczyni się do osiągnięcia dodatkowych korzyści. Grupy przyjmujące tę perspektywę utrzymują, że nierówności społeczne winny być wyrównywane drogą gwarantowania równych szans i akcji afirmatywnych, a kwestie różnic kulturowych, jako nieistotne, winny być pominięte.

Druga perspektywa - dostępu i legitymizacji - w większym stopniu niż poprzednia uwzględnia różnice w wymiarach kulturowych, traktuje je jednak w sposób uproszczony i pragmatyczny. Stosowanie w praktyce tej perspektywy oznacza rozpatrywanie różnic kulturowych jedynie jako źródła dodatkowych korzyści wynikających z dotarcia do nowych klientów dzięki pracownikom reprezentującym nietradycyjne pochodzenie czy niestandardowe wykształcenie. Grupy zakładające tę perspektywę utrzymują, że kulturowe tło jest znaczące jedynie wówczas, gdy ma się do czynienia z mniejszościową populacją.

Trzecia perspektywa - integracji i uczenia się - w odróżnieniu od dwóch poprzednich, umożliwia tworzenie wartości dodanej na bazie umiejętności, doświadczeń i sposobów myślenia pracowników reprezentujących odmienny kapitał kulturowy. Perspektywa ta ułatwia wcielenie podejść poszczególnych pracowników w podstawowe zadania organizacji i umożliwia wzbogacanie samej pracy przez ponowne ich przemyślenie oraz przeorientowanie rynku docelowego, produktów oraz strategii, misji, działań praktycznych oraz kultury (Thomas, Ely, 1996). Różnice postrzegane są jako źródło rozwoju firmy, bodziec do uczenia się, pod warunkiem, że są prawidłowo rozpoznane i konstruktywnie wcielane w struktury organizacyjne.

Zdaniem Argyrisa, Putnama i Smith (1999) oraz Fishera i Torberta (1995) koniecznym warunkiem skutecznego uczenia się w zróżnicowanej grupie jest przyjęcie perspektywy integracji i uczenia się (explicite lub implicite), łącznie z ogólną strukturą refleksyjnego uczenia się i zachowań.

\section{Modelowe ujęcie uczenia się w grupach zróżnicowanych}

Przyjęta przez daną grupę perspektywa różnorodności oraz właściwe jej schematy uczenia się i zachowań oddziałują na siebie, w wyniku czego powstaje określony zbiór struktur uczenia się i działania odnoszących się w sposób szczególny do różnorodności kulturowej. 
Perspektywa integracji i uczenia się aktywizuje ogólne struktury uczenia się i zachowania i jest jedyną perspektywą, która zakłada, że różnorodność kulturowa stanowi źródło wiedzy. W tym względzie podejście to różni się od pozostałych perspektyw różnorodności. Perspektywy rozróżniania i sprawiedliwości oraz dostępu i legitymizacji nie przywiązują dużej wagi do różnorodności, aczkolwiek jej pomijanie $w$ każdej z nich manifestuje się odmiennie. W pierwszej perspektywie pracownicy, chociaż mogą różnić się wyglądem, w tym, co jest najbardziej istotne, są do siebie podobni. Nie bierze się w niej pod uwagę wpływu pochodzenia kulturowego na światopogląd i przekonania. Druga perspektywa nie kwestionuje całkowicie roli środowiska kulturowego, ale postrzega je w zawężony sposób. Takie środowisko liczy się jedynie wówczas, gdy członkowie grupy o określonej tożsamości kulturowej stykają się z przedstawicielami o identycznej tożsamości. Jedynie perspektywa integracji i uczenia się zakłada, że dziedzictwo kulturowe może być źródłem wartościowych doświadczeń, możliwych do wykorzystania w praktyce działań organizacyjnych. Nie odcina się ona od rozróżniania np. koloru skóry; uznaje, że tożsamość grupowa wiele mówi o przeszłych i teraźniejszych doświadczeniach życiowych i wiarygodnie świadczy o tym, kim naprawdę jesteśmy. $\mathrm{W}$ odniesieniu do środowiska pracy w perspektywie tej zakłada się, że różnice stanowią wartościowe zasoby organizacji, ponieważ implikują odmienne opcje i sposoby widzenia oraz kulturowo uwarunkowane sposoby uczenia się (Mazur, 2005), a także, że różne doświadczenia życiowe pozytywnie warunkują sposoby myślenia na temat zadań $\mathrm{w}$ organizacji i ich zaaprobowanie może przyczynić się do efektywniejszej pracy zespołu.

Przyjęcie perspektywy integracji i uczenia się jest warunkiem koniecznym aktywacji struktur uczenia się i zachowań, ale bez przekonań i działań w kwestii uczenia się byłaby ona jedynie perspektywą dodaną, która nie manifestowałaby się istotnie we wspólnej pracy grupy. To właśnie przekonania na temat uczenia się i zachowania umożliwiają grupie przedsięwzięcie trudnego zadania wyrażania i pracy nad kulturowo uwarunkowanymi przekonaniami. Grupom, które przyjęły perspektywę integracji i uczenia się, ale nie wdrożyły komponentu uczenia, brakować może narzędzi uczenia się niezbędnych do wytworzenia środowiska asymilującego umiejętności refleksji nad czyimiś poglądami i przekonaniami. Dlatego każda perspektywa pozbawiona elementu uczenia się może potencjalnie stać się pułapką, a nie szansą. Perspektywa integracji i uczenia się, wraz z ogólnymi strukturami uczenia się i zachowań, stanowi warunek konieczny procesu uczenia się w grupach zróżnicowanych kulturowo, przy czym jeden czynnik warunkuje wystąpienie drugiego.

Interakcje między perspektywą integracji i uczenia się oraz ogólnymi strukturami uczenia się i zachowania umożliwiają wytworzenie się specyficznych struktur 
uczenia się i zachowań odniesionych do różnorodności kulturowej. Na rysunku 1 przedstawiono oparty na tej interakcji model skutecznego uczenia się w grupie kulturowo zróżnicowanej.

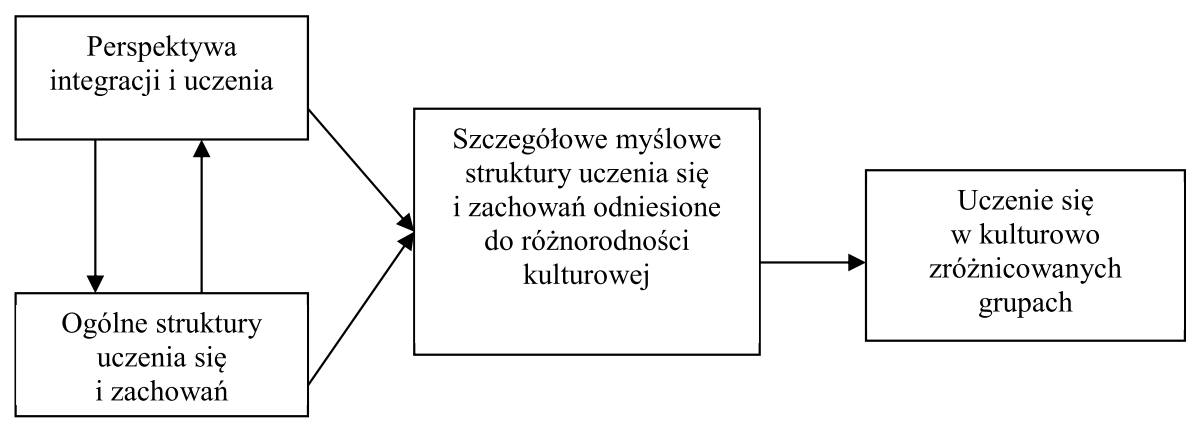

Rysunek 1. Uczenie się w grupach kulturowo różnorodnych

Źródło: Mazur, 2009, s. 39.

Foldy (2004) twierdzi, że struktury skutecznego uczenia się i zachowań odniesione do grup zróżnicowanych ułatwiają uczenie się w takich grupach dzięki temu, że:

- manifestują ideę, że, jak sugeruje perspektywa integracji i uczenia się, różnice kulturowe pozostają istotnym rezerwuarem pomysłów na temat pracy i sposobów jej wykonywania; kulturowe doświadczenia poszczególnych pracowników przyczyniają się do wzbogacenia (poszerzenia i pogłębienia) podejść do pracy członków danej grupy,

- dowodzą, że różnice kulturowe, jako znaczące dla organizacji, winny być analizowane i dyskutowane; jeżeli nie są transparentne, to ich zalety pozostają poza zasięgiem organizacji,

- traktują każdego członka grupy jako odpowiedzialnego za kwestie różnic; każdy jest w posiadaniu jakichś zasobów, które mogą być użyteczne dla wszystkich członków organizacji, od każdego oczekuje się, że będzie otwarty na opinie innych i będzie pomagał wcielać ich doświadczenia w praktyczną działalność grupy; różnice muszą być zatem poddawane pod dyskusję, a każdy członek grupy jest odpowiedzialny za proces własnego uczenia się.

Przedstawione struktury i zachowania umożliwiają skuteczne uczenie się na dwa odmienne sposoby: uczenie się z różnic kulturowych, jako że ułatwiają dyskusje na temat tego, jak owe różnice wpływają na sposób myślenia i pracę grupy oraz uczenie się poprzez różnice kulturowe, ponieważ ułatwiają uczenie się 
o wszystkim, co jest odmienne i co nas otacza, co może nie być bezpośrednio związane z różnicami kulturowymi per se.

Jedynie grupy z perspektywą integracji i uczenia się zakładają, że doświadczenie kulturowe jest źródłem nauki oraz iż doświadczenia członków grup społecznych o odmiennej tożsamości powinny zostać przeniesione do organizacji i przyczynić się do wzbogacenia pracy. Zatem tylko ta perspektywa różnorodności ujmuje różnorodność kulturową w jej społecznym kontekście i podkreśla, że odmienne podejścia do kontekstu społecznego oddziałują na możliwości grupy uczenia się z i poprzez różnice kulturowe.

Idea perspektyw różnorodności, które pośredniczą między heterogenicznością a wydajnością, pomaga w wyjaśnieniu, dlaczego jedne różnorodne kulturowo grupy są bardziej skuteczne w działaniu od drugich.

\section{Podsumowanie}

Od wielu lat budowane jest społeczeństwo informacyjne, którego podstawowym fundamentem jest wiedza. Tworzy ona również podstawy działania każdej organizacji, która musi umieć zarządzać wiedzą, gromadzić ją i przetwarzać. W erze zarzadzania wiedzą w organizacji zagadnienie organizacyjnego uczenia się jest kwestią nie do przecenienia.

Tylko wówczas, kiedy w organizacjach poszczególne grupy przyjmują perspektywę uczenia się i realizują strukturalny schemat refleksyjnego uczenia się i zachowań, może dojść do sprzężonego wzajemnego pobudzania tych elementów grupy. W określonym kontekście perspektywa integracji i uczenia się może podnosić poziom grupowego uczenia się i zachowania; pozwala to także na skierowanie wyzwania uczenia się do właściwej różnorodnej kulturowo grupy. Przekonania i działania grupy umożliwią jej uaktywnienie perspektywy różnorodności - dostarczają narzędzi, za pomocą których grupa może wzajemnie poznawać istniejące w jej obrębie różnice. Znajomość ta jest niezbędna każdemu przedsiębiorstwu działającemu na globalnym rynku.

\section{Bibliografia}

Argyris, C., Putnam, R., Smith, D.M. (1985). Action sciences. San Francisco: Jossey-Bass. Ashforth, B.E., Meal, F. (1989). Social identity theory and the organization. Academy of Management Review, 14 (1), 20-39.

Chatman, J.A., Flynn, F.J. (2001). The influence of demographic heterogeneity on the emergence and consequences of cooperative norms in work team. Academy of Management Journal, 44 (5), 956-974. 
Cichorzewska, M., Rakowska, A. (2016). Zarządzanie różnorodnością zasobów ludzkich w innowacyjnych przedsiębiorstwach - wyniki badań. Przedsiębiorczość i Zarządzanie, 17 (2/3), 89-100.

Earley, P.C., Mosakowski, E. (2000). Creating hybrid team cultures: An empirical test of transnational team functioning. Academy of Management Journal, 43 (1), 26-49.

Ely, R.J., Thomas, P.M. (1997). Demographic diversity in the decision-making groups: The experiences of women and people of colour. Academy of Management Review, 22 (4), 946-973.

Ely, R.J., Thomas, P.M. (2001). Cultural diversity at work: The effects of diversity perspectives on work group processes and outcomes. Administrative Science Quarterly, 46 (2), 229-273.

Fisher, D., Torbert, W. (1995). Personal and organizational transformations. London: The McGraw-Hill Companies.

Foldy, E.G. (2004). Learning from cultural diversity: A theoretical exploration. Public Administration Review, 64 (5), 529-538.

Hubbard, E.E. (2004). The manager's pocket guide to diversity management. Amherst, MA: HRD Press.

Koźmiński, A.K. (2004). Zarządzanie w warunkach niepewności. Warszawa: Wydawnictwo Naukowe PWN.

Mazur, B. (2005). Rola czynnika kultury w procesie uczenia się i nauczania. Prakseologia, $145,159-169$.

Mazur, B. (2009). Zarządzanie w warunkach różnorodności zasobów ludzkich. Białystok: Wydawnictwo WSFiZ w Białymstoku.

Mor Barak, M.E. (2005). Managing diversity. Toward globally inclusive workplace. Thousand Oak, CA: Sage.

Pieterse, A.N., Knippenberg, D.V., Dierendonck, D.V. (2012). Cultural diversity and team performance: The role of team member goal orientation. Academy of Management Journal, 56 (3), 782-804. DOI:10.5465/amj.2010.0992.

Rijamampinina, R., Carmichael, T. (2005). A pragmatic and holistic approach to managing diversity. Problems and Perspectives in Management, 1, 109-117.

Shaw, J.B., Barrett-Power, E. (1998). The effects of diversity on small work group processes and performance. Human Relations, 51 (10), 1307-1325.

Thomas, D.A., Ely, R.J. (1996). Making differences matter: a new paradigm for managing diversity. Harvard Business Review, 74, 79-90.

Trompenaars, F., Hampden-Turner, C. (2005). Zarzadzanie personelem $w$ organizacjach zróżnicowanych kulturowo. Kraków: Oficyna Ekonomiczna. 


\section{Methodological Aspects of Organizational Learning from Diversity}

Keywords: cultural diversity, organization, learning

Summary. Contemporary organizations show a tendency to be less and less culturally homogeneous. As a result of demographic and economic phenomena, many millions of people migrate in search of work and a better life, changing not only the place of residence, but also the cultural environment, which they enter with their own values, norms and rules of conduct. Thus, both employees and enterprises are exposed to diversity. As a result of globalization, migration and integration processes, the human resources of many organizations are nowadays a cultural mix. In the literature on the subject of managing cultural diversity, it is referred to as a double-edged sword that can work for the benefit of the organization or be a burden for it. The role of managers is to make this mix a source of competitive advantage for the organization. To achieve that, organizations must develop ways of learning from culturally diverse members of groups. The base for the paper is the review of literature concerning the subject of methods of learning from culturally diverse organization members. In the light of the research results, the most effective method of learning from cultural diversity is the adoption (by the organization) of specific mental learning structures funded on the perspective of integration and learning and general learning structures.

Translated by Barbara Mazur

\section{Cytowanie}

Mazur, B. (2017). Metodologiczne aspekty uczenia się z różnorodności organizacji. Marketing i Zarzadzanie, 3 (49), 67-78. 